\title{
Sickle cell disease: Awareness, knowledge and attitude among undergraduate students of a Nigerian tertiary educational institution
}

\author{
Ngozi Immaculata Ugwu \\ Haematologist,Haematology and Immunology Unit, Department of Pathology, Faculty of Medicine, Ebonyi State \\ University, Abakaliki, Ebonyi, Nigeria
}

Background: Sickle cell disease (SCD) is an inherited abnormality of the red blood cell characterized by chronic haemolytic anemia with numerous clinical consequences. Aims and Objectives: The objective of this study is to assess the level of awareness, knowledge and attitude to people living with SCD among undergraduate students of a tertiary educational institution in Abakaliki, South eastern, Nigeria. Materials and Methods: A crosssectional descriptive study was carried out, and participants were selected using multistage sampling technique. Data was collected using a pre-tested, self-administered questionnaire and analyzed using SPSS software, version 20. Results: A total of 329 participants were studied, made up of $158(48 \%)$ males and $171(52 \%)$ females. Mean age of the participants was $22.3 \pm 2.7$ years. All the participants $(100 \%)$ were aware of the existence of SCD with lectures $(35 \%)$ and health workers $(19.1 \%)$ being the most common sources of information. One hundred and ninety one (58.1\%) participants showed adequate knowledge about SCD but many of them showed some misconceptions. This study also found that majority of the participants, 291 (88.4\%) have positive attitude towards people living with SCD. Majority of those who have adequate knowledge about SCD showed positive attitude while the reverse is the case for those who have inadequate knowledge. Conclusion: This study found knowledge gaps about SCD among the participants. Health education should be intensified to impact sufficient comprehensive knowledge about SCD to enable the students take informed decision about their marriage so as to prevent procreation of children affected with SCD.

\section{INTRODUCTION}

Sickle cell disease (SCD) is an inherited abnormality of the red blood cell characterized by the presence of abnormal hemoglobin- hemoglobin S, either in homozygous form (Hb SS), called sickle cell anemia or in combination with other abnormal hemoglobins such as sickle cell hemoglobin C disease ( $\mathrm{Hb} \mathrm{SC}$ ) and sickle cell $\beta$-thalassaemia (Hb S $\beta$-Thal). ${ }^{1}$ They all have in common a tendency for the red blood cells to distort into a crescent shape (sickle shape) under certain conditions. The effects include chronic anemia, jaundice, recurrent bone pains, gradual deterioration of tissue and organ function and early mortality. ${ }^{2}$
Sickle cell disorder has been acknowledged to have a global impact by the World Health Organisation (WHO). ${ }^{3}$ The incidence of sickle cell disorder at birth is determined by prevalence of carriers in the population. SCD has a remarkable public health implications for Africa. It contributes the equivalent of $5 \%$ to under-five deaths in Africa, with up to $16 \%$ in West Africa. ${ }^{4}$ In Nigeria, with an estimated carrier prevalence of $24 \%, 20$ per 1000 births are estimated to be affected with SCD, resulting in 150,000 children with SCD born in Nigeria annually. ${ }^{4}$ Thus Nigeria has the largest population of people affected with sickle cell disease in the world. 
Despite the large number of people affected with sickle cell disease, the level of knowledge about sickle cell disease is still low. In Nigeria, various studies have reported poor knowledge of sickle cell disorder among students. A study conducted by Adewuyi among fresh University graduates in Ilorin, Nigeria reported poor knowledge of SCD, as only $43 \%$ of the respondents showed little understanding of the disease. ${ }^{5}$ Similar study conducted in Benin City, Nigeria by Bazuaye et al, ${ }^{6}$ reported that majority of the students $(55.1 \%)$ do not know their genotype and only $18 \%$ had some correct idea about SCD. Knowledge gap has also been shown by a similar study conducted in Jos, Nigeria by Olarewaju et al, ${ }^{7}$ who reported that many of the students $(25.5 \%)$ had wrong belief that SCD is caused by evil spirit. Study from Ghana has also indicated knowledge gap despite the high prevalence of sickle cell carrier status approaching $25 \%$ and the universal newborn screening program being introduce recently in Ghana. ${ }^{8}$ In another study, comparism of the level of knowledge was made among University students in Texas and Enugu, Nigeria, reported that on the average, students are aware of sickle cell anemia and its carrier state, but there is still some knowledge gap about SCD especially among students in non-medically-related faculties many of whom did not know their genotype. ${ }^{9}$

Knowledge about SCD is a way of preventing and controlling the scourge, since people will be better equipped to take informed decision concerning their marriage and the youths are good entry point for interventions aimed at controlling the disease. Since tertiary educational institutions in the country have good representation of Nigerian youths, there is need to assess the level of knowledge, ignorance and misconceptions about sickle cell disease because an understanding of these factors will help to fashion appropriate public health education programs to increase awareness and knowledge of the condition. Several published studies have given varying reports about the knowledge of sickle cell disease among students, ${ }^{5-7}$ but there is paucity of published data on the knowledge of sickle cell disease among students in our locality. The aim of this study is therefore to assess the level of awareness, knowledge and attitude about SCD among undergraduate students of Ebonyi State University, Abakaliki, Nigeria.

\section{MATERIALS AND METHODS}

\section{Study design}

Descriptive cross-sectional study was carried out between September and November 2015 at Ebonyi State University, which is located in Abakaliki, Ebonyi State, South eastern Nigeria.

\section{Sample size}

The sample size for this study was determined using the formula ${ }^{10}$ for estimation of population prevalence and was based on a 95\% confidence level, and a prevalence of knowledge gap about Sickle cell disease among students, which is $73.4 \%$, as reported by a previous study, ${ }^{11}$ and a desirable degree of accuracy set at 0.05 level. Minimum sample size of 303 was calculated. However, 350 questionnaires were given out to account for refusals. Out of this number, 329 were correctly and completely filled. These questionnaires were considered valid and were used for data analysis.

\section{Sampling method}

Multistage sampling technique was used for the study. Simple random sampling by ballot method was used to select four out of the ten faculties existing in the school. Simple random sampling technique by ballot method was also employed to select four departments, one department each out of the four chosen faculties, as well as to select students from the chosen departments.

\section{Study instrument and data collection}

The tool for data collection was a pre-tested, semi-structured self-administered questionnaire. Information sought in the questionnaire included socio-demographic characteristics, knowledge about SCD including misconceptions, cause of SCD and methods of prevention. During data collection, three research assistants were employed to administer the questionnaires. They were adequately trained and mobilized for the exercise and they assisted in the administration and retrieval of the questionnaires.

\section{Data management and analysis \\ Knowledge about SCD}

Eleven variables on the study instrument were used to assess participants' knowledge about sickle cell disease including modes of inheritance and ways of prevention. One mark was awarded for every correctly answered question and zero for every wrongly answered or unanswered question. Getting all the eleven questions on general knowledge of SCD correctly were scored as $100 \%$. Participants who scored $50 \%$ and above were categorized as having adequate knowledge. Those who scored below 50\% were categorized as having inadequate knowledge.

\section{Attitude to people living with SCD}

Seven questions on the study instrument were used to assess respondents' attitude to people living with SCD, with each question having five Likert items. The Likert items were strongly agreed, agreed, indifferent, disagreed, strongly disagreed. Number of responses to each of the Likert items were computed and converted to percentages. 
Data was cleaned for inconsistencies in the responses and was entered into a computer using statistical package for social sciences (SPSS) software, version 20, which was also used for the analysis. Descriptive statistics were used to compute percentages and averages. Chi square test was used to assess the relationship between variables. Results were presented in tables and charts, and expressed as percentages/proportions, means and standard deviation.

\section{Ethical issues}

Approval for this study was gotten from Research and Ethics Committee of the institution. Questionnaires were administered only to students who gave their consent.

\section{RESULTS}

A total of 329 students participated in the study and were made up of $158(48 \%)$ males and $171(52 \%)$ females, with male to female ratio of $1: 1.1$. The ages of the participants ranged between 16 and 36years with mean age of $22.3 \pm 2.7$ years. Most of the participants, $323(98.2 \%)$ were Christians while 305 (92.7\%) were single (Table 1).

All the participants $(100 \%)$ were aware of the existence of SCD. Lectures were the most frequent source of information, $115(35 \%)$. Other sources of information include health workers $63(19.1 \%)$, friends and colleagues $55(16.7 \%)$, family members $37(11.2 \%)$, radio and television 34 (10.3\%), Library 11 (3.3\%), internet 5 (1.5\%) and posters $1(0.3 \%)$ (Figure 1).

One hundred and ninety one $(58.1 \%)$ of the participants have adequate knowledge about SCD (Figure 2). Knowledge

\begin{tabular}{lcc}
$\begin{array}{l}\text { Table 1: Socio-demographic characteristics of } \\
\text { the participants }\end{array}$ & Percentage \\
\hline Characteristics & Frequency & \\
\hline Sex & & 48 \\
Male & 158 & 52 \\
Female & 171 & 100 \\
Total & 329 & \\
Age & & 9.4 \\
$<20$ & 31 & 80.9 \\
$20-25$ & 266 & 9.7 \\
$>25$ & 32 & 100 \\
Total & 329 & \\
Religion & & 98.2 \\
Christianity & 323 & 0 \\
Islam & 0 & 0.3 \\
Traditional & 1 & 1.5 \\
Others & 5 & 100 \\
Total & 329 & \\
Marital status & & 6.7 \\
Married & 22 & 92.7 \\
Single & 305 & 0.6 \\
Divorced & 2 & 100 \\
Total & 329 & \\
\hline
\end{tabular}

about SCD displayed by the participants were as shown in Table 2. Three hundred and seventeen $(96.4 \%)$ participants know that SCD is an inherited disease; 309 (93.9\%) know that SCD affects the red blood cell and can be diagnosed with blood test; $34(10.3 \%)$ believe that SCD is contagious; Only 97 (29.4\%) know the features that are commonly associated with SCD; $242(73.4 \%)$ know that SCD can be detected by haemoglobin genotype; 306 (93\%) know that sickle cell disease can be prevented and 153 (46.5\%) know the ways through which SCD can be prevented. Other knowledge about sickle cell disease displayed by the participants are shown in Table 2. Some of the participants also showed misconceptions about SCD, example SCD is caused by witchcraft, evil spirit, curse by enemies and punishment from God. Sickle cell disease is contagious $34(10.3 \%)$.

This study also show that majority of the participants have positive attitude to people living with SCD, as 308 (93.6\%) agreed that people with SCD should not be isolated from others; 307 (93.3\%) agreed that people with SCD should be enrolled to school with others; $273(83.0 \%)$ agreed to have person with SCD as their room mate; $316(96.0 \%)$ agreed

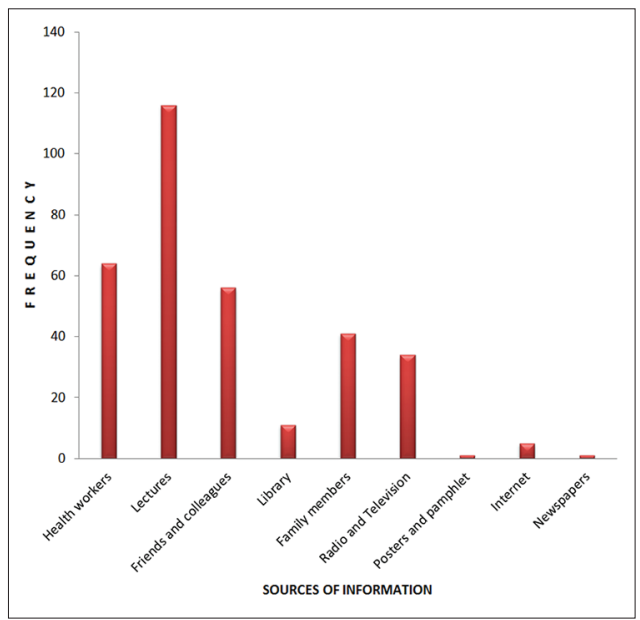

Figure 1: Sources of information about Sickle cell disease

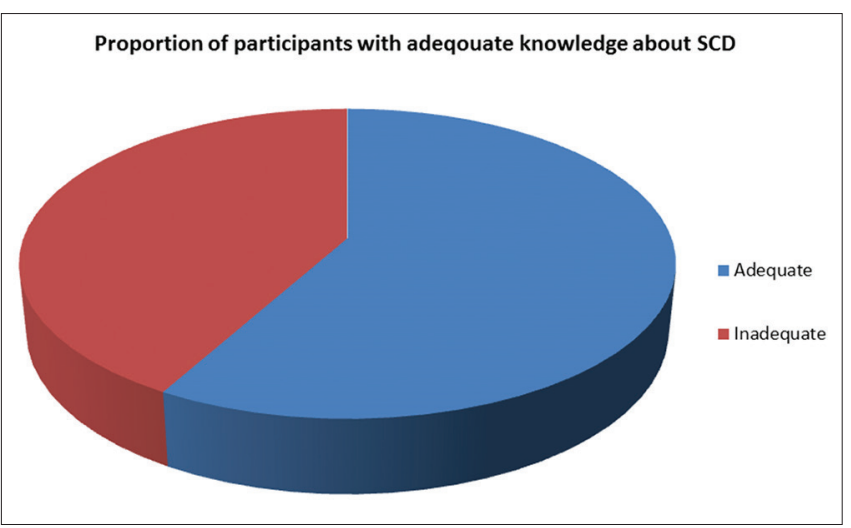

Figure 2: Proportion of students with adequate knowledge about SCD 


\begin{tabular}{lcc}
$\begin{array}{l}\text { Table 2: Participants' knowledge about sickle } \\
\text { cell disease }\end{array}$ & \multicolumn{2}{c}{ Responses N(\%) } \\
\cline { 2 - 3 } Variables & Correct & Incorrect \\
\hline & $317(96.4)$ & $12(3.6)$ \\
\hline $\begin{array}{l}\text { Cause of SCD } \\
\text { Body fluid with which to } \\
\text { diagnose SCD }\end{array}$ & $309(93.9)$ & $20(6.1)$ \\
SCD is contagious & $295(89.7)$ & $34(10.3)$ \\
SCD is curable & $255(77.5)$ & $74(22.5)$ \\
$\begin{array}{l}\text { Component of blood } \\
\text { affected by SCD }\end{array}$ & $309(93.9)$ & $20(6.1)$ \\
SCD can be detected with & & \\
haemoglobin genotype & $242(73.4)$ & $87(26.4)$ \\
$\begin{array}{l}\text { Features commonly } \\
\text { associated with SCD }\end{array}$ & $97(29.4)$ & $232(70.6)$ \\
$\begin{array}{l}\text { SCD can be prevented } \\
\text { Ways of preventing SCD } \\
\text { Chances of SCD in a child }\end{array}$ & $306(93.0)$ & $23(7.0)$ \\
if both parents are carriers \\
$\begin{array}{l}\text { Chances of SCD in a child } \\
\text { if one parent is a carrier }\end{array}$ & $153(46.5)$ & $176(53.5)$ \\
\hline
\end{tabular}

to have person with SCD as their study mate; 311 (94.5\%) agreed to have person with SCD as a friend; $313(95.1 \%)$ agreed to invite person with SCD to their birthday party; $300(91.2 \%)$ agreed to eat with person living with SCD (Table 3).

\section{Knowledge and faculty}

This study also showed that a higher percentage of students from faculty of medicine $(74.9 \%)$, had adequate knowledge compared to students from other faculties: Faculty of Health science and technology (57.9), Faculty of Agriculture (42.0\%) and faculty of law (33.9\%). Association between knowledge and faculty was statistically significant $\left(\mathrm{X}^{2}=48.5, \mathrm{p}=0.0001\right)$.

\section{Knowledge and attitude}

Association between knowledge about SCD and attitude towards people living with $\mathrm{SCD}$ showed that majority of those who had adequate knowledge about SCD displayed positive attitude while majority of those who had inadequate knowledge showed negative attitude, though not statistically significant (Table 4).

\section{DISCUSSION}

This study found that the ages of the participants ranged between 16 and 36 years with equal sex distributions. The participants were all young people most of whom were unmarried making them ideal for the study on knowledge about SCD, as also implicated by previous studies within and outside Nigeria. ${ }^{12,13}$ Knowledge about SCD will help them take informed decision concerning their marriage so as to avoid procreation of children affected with SCD.

\begin{tabular}{|c|c|c|c|}
\hline \multirow{3}{*}{$\begin{array}{l}\text { Attitudinal } \\
\text { statements }\end{array}$} & \multicolumn{3}{|c|}{ N (\%) } \\
\hline & Attitude & Response & \\
\hline & Positive & Negative & Indifferent \\
\hline $\begin{array}{l}\text { People with SCD } \\
\text { should be isolated } \\
\text { from others }\end{array}$ & $308(93.6)$ & $13(4.0)$ & $8(2.4)$ \\
\hline $\begin{array}{l}\text { People with SCD } \\
\text { should not be } \\
\text { enrolled in schools }\end{array}$ & $307(93.3)$ & $17(5.2)$ & $5(1.5)$ \\
\hline $\begin{array}{l}\text { I will accept person } \\
\text { living with SCD as } \\
\text { my room mate }\end{array}$ & $273(83.0)$ & $41(12.5)$ & $15(4.5)$ \\
\hline $\begin{array}{l}\text { I will study with } \\
\text { person living with } \\
\text { SCD }\end{array}$ & $316(96.1)$ & $6(1.8)$ & $7(2.1)$ \\
\hline $\begin{array}{l}\text { I will accept person } \\
\text { living with SCD as } \\
\text { my friend }\end{array}$ & $311(94.5)$ & $13(4.0)$ & $5(1.5)$ \\
\hline $\begin{array}{l}\text { I will invite person } \\
\text { living with SCD to } \\
\text { my birthday party }\end{array}$ & $313(95.1)$ & $7(2.2)$ & $9(2.7)$ \\
\hline $\begin{array}{l}\text { I will eat with person } \\
\text { living with } S C D\end{array}$ & $300(91.2)$ & $22(6.7)$ & $7(2.1)$ \\
\hline
\end{tabular}

Table 4: Relationship between knowledge and
attitude towards people living with SCD

This study also found that all the students have heard and were aware of SCD. This is similar to the report of Gbeneol PK et al, ${ }^{14}$ who also reported awareness of SCD among all the participants studied but Durotoye IA, et al ${ }^{11}$ reported that $79.5 \%$ of their participants had heard about SCD. This may be because their study population were mostly made up of adolescents in secondary school who may not have been exposed to more enlightenment on issues concerning SCD unlike the study population of Gbeneol PK et al, ${ }^{14}$ who were mostly made up of young adult most of whom had secondary and tertiary education. Many of them were married and some were preparing for marriage and in the process were taught about SCD and were also screened for their genotype. Major source of information about SCD include Lectures, health workers, friends and colleagues. This corroborates with the findings of the study conducted in Jos, Nigeria, ${ }^{7}$ which also reported health workers, family members and friends as the major source of information.

Though, all the participants were aware of the existence of SCD, many of them lack adequate comprehensive knowledge about $\mathrm{SCD}$ and exhibited some misconceptions. Some reported that SCD is caused by witchcraft, germs, evil spirit and curse by enemies. Other misconceptions include 
that SCD is contagious, cannot be diagnosed with blood test and cannot be prevented. Similar misconception were also reported by other studies. ${ }^{15,16}$ These knowledge gaps are due to lack of proper education and enlightenment about SCD.

This study also found that students from faculty of medicine had significantly more adequate knowledge compared to students from other faculties. This is not surprising considering the fact that medical students are better exposed to enlightenment about SCD and other health issues compared to students from other faculties. This buttresses the fact that proper education about SCD will help to close the knowledge gaps and equip people to take informed decisions and appropriate actions to control SCD. Similar study conducted among health care workers and medical students showed better knowledge about SCD since they interact more with clients suffering from the disease. ${ }^{17}$

Majority of the participants exhibited positive attitude to people living with SCD. In addition, majority of those who had positive attitude towards people living with SCD were also found to have adequate knowledge about SCD. A higher proportion of those who had negative attitude exhibited inadequate knowledge about SCD. This is similar to findings of other studies. ${ }^{18,19}$ Negative attitude will result to denial and concealment of the disease by the affected individuals as well as carriers, with adverse consequences. Elimination of negative attitude, discrimination and stigmatization depends largely on the extent of enlightenment of the society on issues concerning SCD.

\section{CONCLUSION}

All the students were aware of SCD but many of them lack adequate comprehensive knowledge about SCD and displayed some misconceptions. A higher proportion of the respondents showed positive attitude to people living with SCD and majority of those who had positive attitude were found to have adequate knowledge about SCD while the reverse is the case for those who had negative attitude. Health education should be reinforced to impact adequate comprehensive knowledge about SCD. This will help equip people to take informed decisions and actions as well as to instill into the society the right attitude towards people living with SCD, with consequent prevention and control of SCD.

\section{ACKNOWLEDGEMENT}

The author wish to appreciate the management of Ebonyi State University for permission to carry out the research, concerned Deans and Heads of Departments for their assistance in mobilizing the students, and to the students who consented to take part in the study.

\section{REFERENCES}

1. Okpala IE. The concept of comprehensive care of sickle cell disease. In: Okpala IE (ed). Practical management of haemoglobinopathies. Massachusetts, USA: Blackwell Publisher, 2004; 1-9.

2. Lal A, Vichinsky EP. Sickle cell disease. In: Hoffbrand AV, Catovsky D, Tuddenham EGD and Green AR (ed). Postgraduate Haematology. $6^{\text {th }}$ ed. UK: Wiley-Blackwell, 2011; 109-125.

3. Weatherall DJ and Clegg JB. Inherited hemoglobin disorders: An increasing global health problem. Bull World Health Organ 2001; 79(8): 704-712.

4. World Health Organization: Sickle cell Anemia - report by the secretariat. Fifty ninth World Health Assembly 2006.

5. Adewuyi JO. Knowledge of and attitude to sickle cell disease and sickle carrier screening among new graduates of Nigerian Tertiary Educational Institutions. Postgraduate Medical Journal 2000; 7(3): 120-123.

6. Bazuaye GN and Olayemi EE. Knowledge and attitude of Senior Secondary School Students in Benin City Nigeria to Sickle Cell Disease. World Journal of Medical Sciences 2009; 4(1): 46-49.

7. Olarewaju SO, Enwerem K, Adebimpe WO and Olugbenga-BelloA. Knowledge and attitude of secondary school students in Jos, Nigeria on sickle cell disease. Pan African Medical Journal 2013; 15: 127.

8. Ross PT, Lypson ML, Ursu DC, Everett LA, Rochgues O and Campbell AD. Attitude of Ghanaian women towards genetic testing for sickle cell trait. Inter J Gynae and Obstetrics 2011; 115 (3): 264-268.

9. Ogamdi SO and Onwe F. A pilot study comparing the level of sickle cell disease knowledge in a University in South Eastern Texas and a University in Enugu State, Nigeria. West African Ethn Dis Spring Summer 2000; 10(2): 232-236.

10. Araoye MO. Research methodology with statistics for health and social sciences. Ilorin: Nathadex Publishers, 2003; p 115-129.

11. Durotoye IA, Salaudeen AG, Babatunde AS, Bosah EC and Ajayi FD. Knowledge and Perception of Sickle cell disease among Senior Secondary School students in Illorin Metropolis. The Tropical Journal of Health Sciences 2013; 20(2): 1-7.

12. Alao $\mathrm{OO}$, Araoye $\mathrm{M}$ and Ojabo $\mathrm{C}$. Knowledge of sickle cell disease and haemoglobin electrophoresis: A survey of students of a tertiary institution. Niger J Med 2009; 18(3): 326-329.

13. Alkindi M, Salha AR and Al-Kend M. Knowledge and attitude of University students towards premarital sickle cell screening program. Coman Medical Journal 2012; 27(4): 291-296.

14. Gbeneol PK, Brisibe SF and Ordinioha B. Knowledge, attitude and uptake of premarital screening for sickle trait among married couples in a semi-urban community in South-South Nigeria. European Journal of preventive medicine 2015; 3(3): 49-54.

15. Zounon O, Anani L, Latoundii S, Sorum PC and Mullet E. Misconceptions about sickle cell disease (SCD) among lay people in Benin. Prev Med 2012; 55(3): 251-153.

16. Treadwell MJ and Vinchinsky ML. Using qualitative and quantitative strategies to evaluate knowledge and perceptions about sickle cell disease and sickle cell trait. Journal of National Medical association 2006; 98(5): 704-710.

17. Animasahun BA, Akintoye $\mathrm{CO}$ and Njokanma OF. Sickle cell anemia: Awareness among health professionals and medical 
students at the Lagos University Teaching Hospital, Lagos. Nig Q J Hosp Med 2009; 19(4): 195-199.

18. Ani C, Mayordomo-Aranda A, Kinanee J, Ola B and Kramer T. Trainee-teachers' stigmatising attitude towards sickle cell disorder in Nigeria. European Journal of Educational studies
2012; 4(3): 349-360.

19. Afolayan JA and Jolayemi FT. Parental attitude to Children with sickle cell disease in selected health Facilities in Irepodun Local Government, Kwara State, Nigeria. Ethno Med 2011; 5(1): 33-40.

Authors Contribution:

Ugwu NI: Concept and design of the study, review of the literature, collected data, manuscript preparation and critical revision of the manuscript.

Source of Support: Nil, Conflict of Interest: None declared. 